\title{
Forecasting the future while investigating the past. The use of computational models in pre-trial detention decisions
}

\author{
Prevedere il futuro indagando il passato. L'uso di \\ modelli computazionali nelle decisioni cautelari
}

Serena Quattrocolo ${ }^{1}$

Università del Piemonte orientale, Italy serena.quattrocolo@uniupo.it

https://orcid.org/0000-0002-6746-1130

\begin{abstract}
AвSTRACT: The paper focuses on the traditional purpose of pre-trial detention (and other precautionary measures) to prevent specific risks. While liberty is the rule, before conviction, pre-trial detention is an absolute exception, competing with the opposite principle of the presumption of innocence: providing valuable and accurate justification for balancing the interest to prevent risk with the presumption of innocence is an overarching difficulty for judges, in the whole western world. Which the solutions? The paper reflects and compares the traditional solution of legal presumptions with the newer trend of actuarial assessment tools, based on psycho-criminological theories, based on the Italian and the US federal systems.
\end{abstract}

KEY WORDS: pre-trial detention; presumption of innocence; prediction; behavior; legal presumption; risk assessment.

ABSTRACT: Lo scritto propone una riflessione che prende le mosse dalla funzione tradizionalmente assegnata alle misure cautelari, di prevenzione di specifici rischi endoprocedimentali. Se, infatti, la libertà dell'accusato è la regola, prima dell'accertamento definitivo della sua colpevolezza, la custodia cautelare -

1 Full professor of Italian and European Criminal Procedure; Dean of the Law School, University of Easter Piedmont, Italy; PhD in Criminal Procedure; EUI Fernand Braudel Fellow 2022. 
come strumento estremo di limitazione della libertà personale - non può che essere l'assoluta eccezione, in costante tensione con la presunzione di innocenza. Pertanto, il difficile bilanciamento tra contrapposti interessi presunzione di innocenza e svolgimento del processo - sfocia, a tutte le latitudini, nella necessità di fornire ampia e convincente motivazione alle decisioni cautelari. Quali gli strumenti per raggiungere tale obiettivo? II lavoro pone in relazione la tradizionale soluzione delle presunzioni legali (di pericolosità) e i più recenti strumenti di risk assessment digitale per la valutazione del rischio di recidivanza e comportamento violento, in un parallelo che mette in relazione l'ordinamento italiano e quello statunitense.

KEY WORDS: custodia cautelare; presunzione di innocenza; previsione; comportamento; presunzioni legali; risk assessment.

Summary: 1 . Introducing the topic - 2. The past and the future in criminal judicial decisions: traditional pre-trial detention scopes; 2.1. and the new security purpose; 2.2. how judges can forecast the suspects' future behavior? - 3. Legal presumptions in pre-trial detention; 3.1. in Italy; 3.2. and in the U.S. federal order - 4. What else, instead of presumptions? 4.1. Continental Europe and the German Moderne Schule; 4.2. The US and undetermined sentencing; 4.3. the dawn of risk assessment tools; 4.4 pre-trial risk assessment tools: the PTRA; 4.5. and the PSA - 5. Conclusions.

\section{INTRODUCING THE TOPIC}

In the recent debate about the use of AI and computational models in the realm of justice, much attention has been paid to the alleged ability of such solutions to predict future events. Generally speaking, mathematical models are meant to represent a phenomenon (or a group of phenomena) in descriptive (or normative) terms, in order to allow a prediction of its future replication ${ }^{2}$ : i.e. Having established how and when, given A (a specific condition), B (a specific consequence) occurs, a model allows to establish how likely it is that given a specific input, a specific

2 ISRAEL, G., IANNELLI, M., Modellistica matematica, Enciclopedia Italiana Treccani, VI Appendice, Treccani, Roma, 2000. 
output will be generated. Although a model is not the mirror of reality as reality can be represented by several different models - it is possible to argue that models are meant to predict, statistically, the likelihood of an occurrence, based on the quantitative analysis of a phenomenon. This happens, more or less successfully, in major branches of research: mathematics, physics, medicine, climatology, economics, politics... In very general terms, wherever and whenever the quantitative approach proves relevant (i.e., reliable), a model can be tailored for the purpose to predict the outcome of a process.

The digital turn, based on the amazing boost in computational powers $^{3}$, enlarged the possibility to realise accurate computational models, analysing large database, regularly updated, establishing more accurate correlations. In a nutshell, after the digital turn, computational models can more likely deliver accurate predictions... given that the phenomenon at issue can be reliably tackled with a quantitative approach.

Actually, when human behaviour comes to the attention, the accuracy of the quantitative method is doubtful. While in certain areas of research, such as e.g. customers' habits and decisions, the quantitative approach delivers useful patterns to predict marketing strategies ${ }^{4}$, other aspects of human behaviour are harder to standardise into patterns or, at least, the accuracy of the prediction is far lower ${ }^{5}$. Here is where the issue of the quantitative method, statistics, crosses the realm of justice and, in particular, of criminal justice, raising a huge number of questions.

One general query is: Are there mathematical (and computational) models that can be usefully applied in the criminal proceedings decisionmaking process? Given a general reluctance of legal scholarship towards statistics $^{6}$, the quantitative approach is said to be consistent, while humans

3 PAGAlLO, U., Algo-Rithms and the Beat of the Legal Drum, in Philosophy and Technology, 2018, $1 \mathrm{ff}$.

4 See the seminal work of VON NEUMANN, J., MONRGENSTER, O., Theory of games and economic behavior, Princeton 1944.

5 With specific regard to this topic, see the seminal work of UNDERWOOD, B. D., Law and the Crystal Ball: Predicting Behavior with Statistical Interference and Individualized Judgement, Yale Law Journal, 1979, vol. 88, 1409 ff.

6 WILliAMS, J.F., Classifying Pre-Trial Detention Decisions under the Bail Reform Act of 1984; A Statistical Approach, American Criminal Law Review, 
are not, because they have attitudes, which statistical methods have not... ${ }^{7}$ Without lingering upon the implications of this assumption, it is irrebuttable that statistics helps to identify and weight different factors relevant in a decision process, to confirm individual suspicions and, in particular, to allow others to replicate a decisional process ${ }^{8}$. For these reasons, statistics entered criminal courtrooms and made it into the criminal evidence system, whenever a probabilistic issue interferes into the causation chain. Nevertheless, there is a long-lasting distress in using class-generated probabilities to prove the liability or guilt of an individual ${ }^{9}$.

In particular, there is a more specific matter upon which we need to dwell: Are there aspects of the criminal proceedings decisionmaking process in which there is need to forecast a human behaviour? As I pointed out in other occasions ${ }^{10}$, regardless the national jurisdiction, and despite the assumptions above, criminal proceedings and trials often depend upon predictions of the defendants' future behaviour, that judges must deliver, although the law does not provide for a clear set of criteria (or, more often, without a complete set of information). Moreover, it was noted that the need to forecast a human behaviour within the context of justice implies not only a matter of accuracy - like in any branch of science - but also a matter of other competing values that cannot be overlooked, such as individuals' autonomy ${ }^{11}$. Actually, accuracy appears to lose momentum, in relation to the individuals' autonomy which, despite an extremely precise prediction, yet allows humans to choose to depart from a forecasted behaviour; but also, when it comes to the criminal setting, other values, such as the presumption

1993, Vol. 30, p. 285.

7 WILLIAMS, J.F., Classifying Pre-Trial Detention, p. 286.

8 The topic reaches far beyond the scope of this paper. For our purposes, suffice it to recall HOGART, R.M., Judgement and Choice, $2^{\text {nd }}$ ed., Wiley, Hoboken, p. 49.

9 UNDERWOOD, B. D., Law and the Crystal Ball, p. 1415.

10 QUATTROCOLO S., Artificial Intelligence, Computational Models and Criminal Proceedings. A Framework for a European Legal Discussion, Springer, Cham, 2020, p. 131 ff.

11 UNDERWOOD, B. D., Law and the Crystal Ball, p. 414; 
of innocence, the b.a.r.d., the public faith in the humanity of the legal system $^{12}$, clash with accuracy.

Nevertheless, (and with some approximation between legal orders), it is possible to say that there are at least two crucial decisions based on predictions. The first and most general decision (because it comes with every conviction) is sentencing: depending upon the different theory (or theories) of punishment accepted by a legal order, a larger or smaller portion of sentence is based on the risk of reoffending. The reasons for this have been largely researched over the decades and the literature is burgeoning. In such panorama, the digital turn revitalised the debate upon the reliability of risk assessment tools, based on psycho-criminological theories. Especially in the overseas common law jurisdictions, the tradition in psycho-criminological studies brought to an early introduction of risk assessment tools, used in sentencing to establish rates of risk of reoffending, as briefly reported hereinafter (\$4.2). The second and more specific context is that of pre-trial detention, under the spotlight in this paper. In fact, also at the pre-trial detention stage there is massive reliance upon forecasts by the judicial authority about the accused's future conduct, regardless the national legal order. In such scenario, it is important to reflect upon this aspect: given the huge impact of prediction in the area of pre-trial detention, which is the room for computational models in guiding the judicial decision between liberty and detention (which is an absolute exception, at the pre-trial stage)?

Based on the aim of answering this question (that is a specification of the original one 'are there mathematical and computational models that can be usefully applied in the criminal proceedings decision-making process?'), the paper is structured upon the following steps: i) a brief overview on the most common reasons justifying pre-trial detention in the western legal culture; ii) the main different approaches to pre-trial detention in common law and in civil law countries, with specific regard to Italy; iii) the impact of prediction in pre-trial detention decisions; iv) the alternatives to tackle the demanding task of prediction: risk assessment tools, with specific regard to the U.S. Public Safety Assessment;

12 TRIBE, L.H., Trial by mathematics: Precision and Ritual in the Legal process, Harvard Law Rev., 1971, vol. 84, p. 1368 ff. 
v) presumptions of dangerousness, with specific regard to art. $275 \mathrm{co} .3$ of the Italian Code of Criminal Procedure; vi) a comparative approach and some conclusions.

\section{THE PAST AND THE FUTURE IN CRIMINAL JUDICIAL DECISIONS: TRADITIONAL PRE-TRIAL DETENTION SCOPES}

Moving from the title of this paper, a crucial assumption for the topic under discussion is that «in almost no other circumstances is the court called upon to make predictions about future conduct rather than to determine and punish events which have taken place in the past».13 Actually, what appears to be a patent paradox is the basis for the whole discussion about the use of computational models in criminal justice decisions.

Every criminal proceeding pursues the goal of delivering a decision upon the charge against the defendants: assessing their acts and their personal responsibility for the offence occurred is the very purpose of any criminal proceeding, in any jurisdiction. The assessment of guilt beyond any reasonable doubt entails, at some conditions, the punishment of the convicted ones. However, in framing the boundaries of this discussion, two caveat are necessary.

On the one hand, whereas the purpose of criminal proceedings is straightforward, there is no clear and general understatement of the purposes of punishment: the lack of consensus about the very function(s) of punishment appears in sentencing, in the most evident way. ${ }^{14}$ «Deterrence, retribution, rehabilitation and dangerousness represent the main competing ideologies whose implications clash with each other». ${ }^{15}$ The whole philosophical debate about the aim of criminal sanctions is mainly influenced by the opposing ideas of retribution (based on rigorous proportionality between criminal act and sanction), and

13 VOGLER, R., England and Wales, in S. Ruggeri (ed), Liberty and Security in Europe, Universitätsverlag Osnabrück, Göttingen, 2013, p. 88.

14 LACEY, N., State Punishment, Rutledge, London-New York, 1988, p. 16 ff.

15 NORRIE A., Crime, Reason and History. A Critical Introduction to Criminal Law, CUP, Cambridge, 2014, p. 335. 
incapacitation (based on the perpetrator's social dangerousness, meant to protect society from further harm). Indeed, an evaluation of criminal dangerousness cannot but be based on past facts, in order to identify possible risks of future misbehaviour. Thus, if punishment is also aimed at protecting the society from the defendants' possible reoffending, there is a shift, at sentencing, of the court's attention from the acts the individuals were charged with, towards a prediction of other crimes that they may perpetrate in the future. This assumption is crucial to approach the topic of computational models of risk assessment that will be presented hereinafter.

On the other hand, along the process bringing the court to rule upon the defendants' guilt, there may be other crucial decisions, based upon the facts of the proceeding. Arrest and early stage charges may trigger a judicial decision upon pre-trial detention, based on the need to prevent a list of specific risks.

Although there is no uniformity between jurisdictions, it is possible to argue that the risks traditionally tackled with pre-trial detention tend to be common to the whole area of the western legal tradition. Actually, the international bills of rights, such as art. 9 and 12 of the ICCPR and art. 5 of the European Convention of Human Rights, testify of such common approach.

In fact, it is a fundamental principle of modern law that limitations to liberty before the final assessment of the defendant's culpability should be exceptional, based on exhaustive reasoning, in order to prevent unlawful anticipation of a possible penalty ${ }^{16}$. Such a principle is traditionally referred to the Magna Charta Libertatum, and the refusal of pre-trial release, in England and Wales, is still considered to be the solitary exception to the 1215 Bill of Rights. ${ }^{17}$ In compliance with that ancient and well-regarded principle, pre-trial

16 The issue of pre-trial detention and liberty was crucial in the English Medieval context, with circuit courts travelling around the country, hearing cases after long periods of time. It was up to the sheriff to rule upon the accused's liberty pending trial (FANUELE C., La libertà su cauzione: unpalternativa alla custodia cautelare, Cedam, Padova, 2016, p. 136).

17 CAVADINO P., GIBSON B., Bail, The Law, Best Practice and the Debate, Waterside Press, Hook, 1993, p. 69. 
precautionary measures have been used «to support the main criminal process (the sole justification for the derogation from Magna Charta and Art. 5 ECHR)». ${ }^{18}$ Despite the huge divergence between national legal orders in terms of pre-trial detention regulation ${ }^{19}$ (not only due to the alternative common law / civil law), it is possible to argue that exceptions to the general rule of freedom before final conviction are meant to prevent risks for the trial to come ${ }^{20}$. Having said this, it is possible to argue that the main interference with liberty is the risk of flight: first and foremost, temporary forms of incapacitation aim to prevent the defendant from absconding and, therefore, jeopardising the prosecution and the proceedings.

Although there is major inconsistency between western jurisdictions with regard to the defendant's presence in court, preventing flight with precautionary measures is a common goal (the following references to Europe and U.S. are meant to point main areas of legal influence, as this paper is not based on a proper comparative research basis). Actually, despite being present in court is considered to be a fundamental right of the accused (art. $14 \S 3$ lett. d ICCPR; art. $6 \S 1$ and 3 ECHR, according to the interpretation by the ECtHR), in many legal orders, presence is also considered to be a duty and trial cannot take place without the defendant's participation. From an historical standpoint, there is no clear distinction between common law and civil law countries ${ }^{21}$ : while the former usually prescribe mandatory presence of the defendant, the latter vary a lot, with some

18 VOGLER, R., England and Wales, p. 89.

19 For example, under the viewpoint of the prerequisites of pre-trial detention. Still valuable is ALSCHULER, A.W., Preventive Pre-Trial Detention and the Failure of Interest-balancing Approached to Due Process, Michigan Law Rev., 1986, vol. 85, Issue 3, p. 520 ff., esp. 567, acknowledging that the failure of the 1984 Federal bail Reform Act to introduce proof of wrongdoing as a prerequisite of pre-trial detention rendered the Act unconstitutional («the statutory language looks to the future rather than the past; importing a requirement of proof of past misconduct into this language seems impossible»).

20 TRIBE, L.H., An Ounce Of Detention: Preventive Justice in the World of John Mithcell, Virginia Law Review, 1970, vol. 56, p. 407, arguing that «an accusation of crime should not subject any man to imprisonment unless the government's need to prosecute him compels incarceration».

21 NEGRI D., L'imputato presente al processo, Giappichelli, Torino, 2014, p. 86 ff. 
jurisdiction, like Spain, prohibiting in absentia trials at the highest level, with a constitutional provision. Moreover, recent comparative studies ${ }^{22}$ proved that even in England and Wales there are nowadays major exceptions to the exclusion of in absentia trials, blurring the distinction between right and duty to be present at trial. Not only the defendant's personal participation distinguishes between in absentia and in presence trials, it also plays major consequences upon the whole proceeding ${ }^{23}$, with specific regard to evidence, plea bargaining (and other diversion) decisions, compensation of damages and, of course, the possibility to enforce the final decision. For these reasons, preventing the defendant from absconding is a major commitment of every jurisdiction, regardless the value given to the defendant's personal participation in trial.

Moreover, pre-trial precautionary measures are also meant to prevent the accused from tampering with evidence. ${ }^{24}$

In Europe, the risk of foul play with evidence is considered to be a traditional ground for pre-trial detention, although art. 5 ECHR does not mention it explicitly. Art. 274 lett. a of the Italian code of criminal procedure is a paradigmatic example of how the risk of tampering evidence can be misinterpreted, in order to pursue an unlawful pressure upon the accused, with the purpose to overcome her right to keep silent. Generally speaking, when the defendants belong to criminal organisations, it is likely that European courts may presume a risk of evidence tampering, having regard to the capability of such organisations to interfere with witnesses and victims, intimidating them ${ }^{25}$.

Even in the common law area and, in particular, in the US, according to $\S 3142$ lett. f of the 1984 Bail Reform Act (in 1984 the Crime

22 QUATTROCOLO S., RUGGERI S., Personal Participation in Criminal Proceedings, Springer, Cham, 2019, p. 458. QUATTROCOLO S., RUGGERI S., Personal Participation, p. $461 \mathrm{ff}$.

24 RUGGERI S., Comparative analysis of pre-trial precautionary measures in criminal proceedings, in Ruggeri S., (ed), Liberty and Security in Europe, Universitätsverlag Osnabrück, Göttingen, 2013, p. 227.

25 JUNG S., PETRICK, C., SCHILLER E.M., MUNSTER, L., Developments in German Criminal Law: The Urgent Issues regarding Prolonged Pre-Trial Detention in Germany, German Criminal Law, 2021, p. 307 s. 
Control Act amended the 1966 Bail Reform Act: today, in federal criminal proceedings, release and detention determinations are still governed by $\S \S 3141-3156$ of the 1984 Act), a detention hearing may be triggered by the government or the judicial officer when there is a serious risk that the defendant will obstruct justice, also by intimidating witness and jurors. In such circumstances, detention may be ordered if there is no condition or combination of conditions assuring the safety of any other person and the community ${ }^{26}$. In particular, an outdated but still interesting quantitative study upon pre-trial detention in several US circuits demonstrated that the risk of obstructing justice tends to outweigh other factors and variable in the application of pre-trial detention ${ }^{27}$.

In these terms, the traditional function of pre-trial detention, i.e., supporting the main criminal process, seems to be a common feature, making sense of the exceptional circumstance of depriving individuals of their liberty, without a (final) assessment of their guilt.

\subsection{AND THE NEW SECURITY PURPOSE}

Yet, comparative studies established that, over the recent decades, many European jurisdictions departed from this tradition, to promote, instead, policing and social control goals. ${ }^{28}$ Analysing the reasons for enlarging the list of grounds for pre-trial detention would fall out of the scope if this paper. The reasons underpinning national criminal policies of pre-trial detention may be very difficult to grab and a whole comprehensive study would be needed to establish the causes of the reported phenomenon. For example, a regarded comparative American study considered the German reform of 1964, introducing a brand-new case of pretrial detention, based on the risk of serious offences, a consequence of the German accession to the ECHR. Although the accession did not imply the introduction of less liberal conditions,

26 WILLIAMS J.F., Classifying Pre-Trial, p.264, p. 272.

27 WILLIAMS J.F., Classifying Pre-Trial, p. 298.

28 ORLANDI, R., Introduction, in RUGGERI S. (ed), Liberty and Security in Europe, Universitätsverlag Osnabrück, Göttingen, 2013, p. 10 
a new case of pre-trial detention was introduced for suspects having committed serious sex crimes ${ }^{29}$.

Despite the general acknowledgement of the presumption of innocence - recognised both in Europe and in the US - the trend mentioned above proved that, in recent years, the specific purposes distinguishing pre-trial detention from punishment tend to blur. Including new legal basis for precautionary measures, based on the need to prevent serious crimes, is not the only reason for anticipating the effect of penalty, via remand in custody and other interim measures. Among others, is the unreasonable length of criminal proceedings, ${ }^{30}$ certified in many States of the Council of Europe by the European Court of Human Rights (Italy above all others). Given that the causes for increasing the use of pre-trial detention are manifold, the consequence of such a trend was coherent, focusing the public opinion more on custody than on punishment, fostering the public expectation for an early and immediate deprivation of liberty, regardless the effective assessment of guilt and sentencing. The effect of this tendency is a major threat to the presumption of innocence, ${ }^{31}$ as testified by comprehensive literature on the topic. ${ }^{32}$

The same arguments seem to be valid for the U.S. too. Protecting the community was not a traditional task of pre-trial detention ${ }^{33}$ until the Eighties of the XX century. In 1984, the Bail Reform Act (see supra), introduced the 'danger to the community' as legitimate grounds for pre-

29 MEYER, H.H., Constitutionality of Pretrial Detention, The Georgetown Law Journal, 1972, vol. 60, n. 6, p. 1469 ff.

30 ORLANDI R. Introduction, p. 11.

31 VOGLER R., England and Wales, p. 89: «nothing could do more damage to the adversarial principle that to imprison one adversary so that the logistical difficulties of the case preparation are magnified and he or she will appear in court robbed of any opportunity of appearing as an innocent person».

32 As to Spain, MORENO CATENA V., Spain, in S. Ruggeri (ed), Liberty and Security in Europe, Universitätsverlag Osnabrück, Göttingen, 2013, p. 154 ff.; as to Italy, see recently, DANIELE, M., Habeas Corpus. Manipolazioni di una garanzia, Giappichelli, Torino, 2017, p. 77 ff.; GREVI V., Libertà provvisoria ed esigenze di tutela ella collettività: una questione di legittimità costituzionale, Giur.it., II, 1976, p. 633 ff.

33 See extensively, WILLIAMS, J.F., Classifying Pre-Trial, p. 256 ff.; see also LOGAN KOEPKE J., ROBINSON D.G., Danger Ahead: Risk Assessment and the Future of Bail Reform, Washington Law Review, 2018, p. 1731 ff. 
trial detention ${ }^{34}$. In recent years, only a few States regulations of pre-trial detention refer exclusively to the consideration for court appearance. ${ }^{35}$ The US Supreme Court up-held this new task of remand in custody, stressing that «the Government's regulatory interest in community safety can, in appropriate circumstances, outweigh an individual's liberty interest». ${ }^{36}$ Interestingly, in the quoted case of Salerno, the US Supreme Court came to a particular conclusion: based on the lack of intent to punish, pre-trial detention ordered at the detention hearing for the purpose of preventing crimes must be considered regulatory rather than punitive. Despite the criticism about such conclusion ${ }^{37}$, the Court never overruled that decision and prevention of (re?)offending became an accepted grounds for remand on custody.

\subsection{HOW JUDGES CAN FORECAST THE SUSPECTS' FUTURE BEHAVIOR?}

Given this general overview, the conclusion is that recent history of the western legal area demonstrates an expansion in the application of predictions in the field of precautionary measures, limiting individuals' liberty before (and pending) trial. However, being exceptional, the decisions about pre-trail detention (and other coercive measures) must

34 WILLIAMS, J.F., Classifying Pre-Trial, p. 257; ALSCHULER A.W., Preventive Pre-Trial Detention, p. 510 ff.

35 VAN NOSTRAND, M., Legal and Evidence Based Practices: Application of Legal Principles, Laws, and Research to the Field of Pretrial Services, 2007, Crime and Justice institute - National Institute of Corrections, US Dept. Of Justice, 2012, p. 2.

36 US Supreme Court, US v. Salerno (decided on 26 May 1987), 481 U.S. 739. However, in that very same decision, Justice Rehnquist, signing the opinion of the Court, stressed that «the legislative history of the Bail Reform Act clearly indicates that Congress did not formulate the pretrial detention provisions as punishment for dangerous individuals» and that «in our society, liberty is the norm, and detention prior to trial or without trial is the carefully limited exception. We hold that the provisions for pretrial detention in the Bail Reform Act of 1984 fall within that carefully limited exception».

37 There were dissenting opinions, arguing that the majority had overlooked the undeniable punitive element of pre-trial detention: see KISELBACH, D., Pre-Trial Criminal Procedure: Preventive Detention and the Presumption of Innocence, in Criminal Law Quarterly, 1989, vol. 31, n. 2., p. 171. 
be justified by strong reasoning, in order to prevent abuses, as expressly provided by several domestic constitutions. ${ }^{38}$ And the more custody serves social security (rather than procedural) goals, the higher becomes the need for precise justification. But how can judicial authorities deliver precise reasoning about the risks of the suspect's future behaviour?

Before we move any further into the topic of this paper, there are some important premises. First. As said, rules of criminal procedure seldom provide the decision maker with precise criteria for delivering an accurate risk assessment ${ }^{39}$ : be it a matter of predicting the risk of absconding, or obstructing justice by tempering evidence, or committing a serious offence, judges are seldom equipped with valuable and accurate criteria to forecast the defendant's future behaviour. Second. Even if the law or case-law provide for precise parameters, remand in custody and similar coercive measures are usually applied at an early stage of the proceedings, when the competent authorities have little information about both the facts that occurred and the suspect's personality, as the file is still incomplete.

In this scenario, two different solutions gained momentum. Traditionally, the difficulty of forecasting an individual's future behaviour in pre-trial decisions has been tackled with presumptions. Although this should be the object of a specific comparative study, it is possible to argue, with some approximation, that the majority of the western legal orders recur to presumptions to establish the existence of a specific risk justifying detention (or other precautionary measures limiting liberty) before the assessment of guilt beyond any reasonable doubt. Such presumptions are various: They may be established by the law (see art. 275.3 of the Italian code of criminal procedure) or by consistent case-law ${ }^{40}$; they are often

38 RUGGERI, S., Comparative Analysis, p. 230.

39 The Italian system, based on art. 274 lett. c ItCCP, provides for specific criteria. To decide a pre-trial coercive measure, justified by the risk of offending, the judge must consider: specific circumstances of the fact (of which the individual is suspected); the suspect's personality, based on her behaviour, deeds and record of previous convictions.

40 See JUNG, S., PETRICK, C., SCHILLER, E.M., MUNSTER L., Developments, p. 308, with regard to the attitude of German local courts to be satisfied with the circumstance that criminal organisations are likely to tamper with evidence, taking advantage of their innate power of intimidating. 
rebuttable, but they may also imply some irrebuttable consequences (see, again, the example of art. 275.3 ItCCP, hereinafter). Generally speaking, legal presumptions hardly reconcile with the scheme of fair trial, reducing the space for an effective defence: if rebuttable, they reverse the burden of proof from the authorities upon the defendant, relieving the former from the duty of providing precise reasoning; if irrebuttable, they simply deprive the latter of the right to demonstrate the specificity of his/her own situation, excluding judicial authorities' discretion and, thus, their duty to provide reasoning for their decisions. Moreover, the pre-trial context is a fluid one: investigation may introduce new elements, to change the scenario and presumptions are not compatible with it ${ }^{41}$. Such pattern appears to be particularly controversial with regard to pre-trial detention, as liberty is supposed to be the rule and incarceration or incapacitation an absolute exception...

As an alternative to traditional presumptions, models based on psycho-criminological, statistical theories also appear to offer a great support, giving the judicial reasoning the 'fuel' it needs, in the context of precautionary measures. Not only sentencing is a 'natural' scenario for risk assessment (manual or digital) tools (see § 4): detention hearings and other judicial decisions upon remand on custody (and other precautionary measures) became, more and more, the floor for predictions. And the more human decisions prove inconsistent, the more presumptions appear to violate individual's right to a fair trial, the more the quantitative approach seems to be the solution. But is it a valuable solution? Let us reflect upon this.

\section{LEGAL PRESUMPTIONS IN PRE-TRIAL DETENTION}

Legal presumptions are a familiar concept in the European context. Given their ancient root in the Byzantine law $^{42}$, presumptions became a common legal instrument in the Napoleonic period, in private

41 CENTORAME, F., Presunzioni di pericolosità e coercizione cautelare, Giappichelli, Torino, 2016, p. 115.

42 ANDRIOLI, V., Presunzioni (dir. proc. civ.), Novissimo Digesto Italiano, vol. XIII, Utet, Torino, 1966, p. 765 ff. 
law. According to art. 1349 of the Code Napoléon, presumptions are epistemological statements, implying that the judge can infer a specific unknown fact from a specific known fact ${ }^{43}$.

Actually, the Napoleonian definition encompasses two different aspects $^{44}$ : legal presumptions, in which the ruler sets the boundaries of the link between the known fact and the unknown one; basic presumptions, praesumptiones hominis, allowing the judge to draw conclusions from common sense. For the purpose of this work, what is relevant is legal presumptions, whose purpose was, and still is, to limit the judicial discretion in the appreciation of evidence. Insofar, the purpose of presumptions appears very similar to that of mathematical models, as defined above, although the method is not: while models - may they be descriptive or normative - are based on a scientific theory attempting to reproduce reality, presumptions are based on a legal assumption, that may be not validated.

Without lingering upon historical aspects, it is possible to argue that legal presumptions almost lost their epistemic value as a consequence of the endorsement of b.a.r.d. and, in general, fair trial; however, an area in which legal presumptions did not lose momentum, is that of precautionary measures. Two cases appear very meaningful.

\subsection{IN ITALY}

The Italian criminal justice system was completely renewed in 1988 , with a new code of criminal procedure. Abandoning the traditional inquisitorial scheme, the new code did not provide for legal presumptions in the field of pre-trial detention. Along with other provisions, art. 275 ItCCP set forth a system of individualised judicial decisions, based on the need to satisfy specific requirements as to: i) proof of wrongdoing, and absence of excuses; ii) seriousness of the alleged misconduct; iii) existence of at least one specific risk among: evidence tampering; absconding; committing serious offences; iv) proportionality of the measure with the

43 See art. 1349 Code Napoléon: « Les présomptions sont des conséquences que la loi ou le magistrat tire d'un fait connu à un fait inconnu».

DELVECCHIO, F., Presunzioni legali e rieducazione del condannato, Giappichelli, Torino 2002, p. 11. 
alleged misconduct; v) pre-trial detention as last resort measure, when no other conditions (or sets of measures) can reasonably prevent the risk under (iii). Each decision is triggered by a public prosecutor's request and is delivered by a judge, along with specific reasoning: both the accused and the prosecutor may challenge the judicial decision, with specific means of appeal, before a court of merits and even before the Supreme Court.

In this context, art. 275.3 ItCCP was soon amended (by some urgent reforms, passed by the Government, and upheld by the Parliament, in 1991), in order to introduce a double presumption, for a list of organised crimes. With regard to such crimes, if there is proof of wrongdoing (i) and a risk in letting the suspect at large (iii), the judge must order pre-trial detention and pre-trial detention only, with a two-tier system: a rebuttable presumption (about wrong doing and risks: the accused is allowed to demonstrate that there is no proof, of the wrongdoing and of risk...) and an irrebuttable one. If the rebuttable presumption is not reversed by the accused, remand on custody will be ordered, as it is presumed that, given the accused's affiliation to a criminal organisation, the sole effective measure is detention. The purpose of the amendment was to relieve judges from the duty to provide precise reasoning for remand in custody of members of powerful criminal organisations: setting a presumption would free the judge from a discretionary decision and, possibly, from the risk of retaliation. After a reduction, in 1995, the list of crimes implying the two-tier presumption was widely enlarged in 2009 , with no connection to organised crime. Such trend triggered several appeals to the Italian Constitutional Court, that, in 2010, quashed the irrebuttable presumption, transforming it into a rebuttable one (with regard to some of the crimes enlisted in art. 275.3 ItCCP $)^{45}$. The Court found several violations of the Italian Constitution: art. 3, establishing equal protection of individuals under the law (as to the lack of coherence in the list of offences triggering the presumptions); art. 13, setting forth the principle that liberty is the rule and pre-trial detention an extremely specific exception; art. 27,

45 The literature about this topic is burgeoning. The core-concept is perfectly reported in the decision 265/2010 of the Italian Constitutional Court, which is, in my opinion, the best reading for non-Italian scholars interested in the topic (https://www.cortecostituzionale.it/stampaPronunciaServlet?anno=2010\&numero=265\&tipoView $=$ P\&tipoVisualizzazione $=$ ) 
providing that punishment must have a rehabilitation purpose (as to the punitive effect triggered by the presumption system).

At the time of writing, as a consequence of several others decision by the Constitutional Court and a series of amendments, the Italian rule about presumptions reads as follows: the original two-tier presumption still applies for three specific crimes (sedition, terrorism, affiliation to mafia organisations); in case of proof of wrongdoing, remand on custody is ordered, unless there is proof of no risk at all in leaving the suspect at large; for a (non-coherent) list of other crimes, there is a double rebuttable presumption, allowing the suspect to demonstrate: i) that there is no proof of wrongdoing or risk in being let at large; ii) if (i) is not reversed, other less punitive measures are suitable to balance the risk.

As a matter of fact, Italy just reduced, but did not abandon, presumptions in the application of pre-trial detention, upholding even the arguable irrebuttable presumption for terrorism and affiliation to mafia: the internal debate, however, is far from being over ${ }^{46}$ and further interventions by the Constitutional Court have been envisaged ${ }^{47}$.

\subsection{AND IN THE U.S. FEDERAL ORDER}

For almost two centuries, the US federal system had established the right to bail for individuals accused of non -capital punishment crimes, based on their capability to provide sureties ${ }^{48}$. Traditionally, at the federal level, bail was ruled by three basic rules: bail should not be excessive; a right to bail exists in non-capital cases; bail is meant to assure

46 GIULIANI, L., La libertà personale dell'imputato dopo la 1. 16 aprile 2015, n. 47, in Rivista di Diritto Processuale, 2017, p. 168.

47 ZACCHÉ, F., La libertà personale tra diritti della persona e nuove sfide del processo penale, in Rivista Italiana di Diritto e Procedura Penale, 2020, 2006 ff.; DANIELE, M., Habeas Corpus. Manipolazioni di una garanzia, Giappichelli, Torino, 2017, 108 ff.; Others value the irrebuttable presumption with regard to terrorism: MANES, V., Lo 'sciame di precedenti' della Corte costituzionale sulle presunzioni in materia cautelare, in Diritto Penale e Processo, 2014, p. 466.

48 SCHNACKE, T. R., JONES, M. R., BROOKER, C.M.B, The History of Bail and Pretrial Release, Pretrial Justice Insititute, 2010; TONDI, V., Il bail. La libertà su cauzione negli ordinamenti anglosassoni, Cedam, Padova, 2016, p. 17. 
the presence of the accused at trial. However, as a matter of fact, the right to release was submitted to wealth ${ }^{49}$, although in accordance with the principle of non-excessive bail, set forth by the VIII Amendment to the Federal Constitution.

During the Sixties of the $20^{\text {th }}$ century, the disappointment for a situation linking liberty to wealth was growing and under the initiative of the US Attorney General, Robert Kennedy, a National Conference on Bail and Criminal Justice was held in May $1964^{50}$, paving the way to the 1966 Bail Reform Act.

It is in the wake of such reform that, with the purpose to detach release from financial conditions, the attention started to be moved from the ends of justice to the needs of public interest (as openly stated by the 1966 Act itself). The trend grew over the decades, until in 1984 the standard of presumptive favour for release pending trial was replaced, with regard to serious offence, by the reverse presumption of custody ${ }^{51}$. According to the 1984 Bail reform act, two groups of conditions justify such reversal, introducing - like in the Italian experience - the presumption that only remand in custody is effective ${ }^{52}$. The so called 'Previous Violator Presumption'53 and the 'Drug and Firearm Offender Presumption' have long been applied and are based on specific tests, daily applied by courts.

49 AUSTIN, A., The Presumption for Detention Statute's Relationship to Release Rates, in Federal Probation, 2017, vol. 81, no. 1, p. 52.

50 SCHNACKE, T. R., JONES, M. R., BROOKER, C. M.B,: The History, p. 11.

51 A 1981 report from the Attorney General task force on violent crime concluded that the 1966 Bail Reform Act should be amended in order to: deny bail to dangerous individuals; deny bail to individuals accused of serious crime, having already committed previous bail crimes; reversing, for serious crime, the presumption in favour of liberty (see AUSTIN A., The Presumption, p. 52).

52 WILLIAMS F.J., Classifying Pre Trial, p. 268 ff.

53 The presumption applies to individuals charged with: any crime of violence or act of terrorism with a statutory maximum term of imprisonment of 10 years or more; any drug offense with a statutory maximum term of imprisonment of 10 years or more; any felony involving a minor victim; any felony involving the use or possession of a firearm or destructive device; a charge for Failure to Register as a Sex Offender; any felony with a statutory maximum sentence of life or death; any felony if the defendant has at least two prior felony convictions for one of the above-noted offenses at the federal, 
As said above, and unlike in the Italian jurisdiction, the Supreme Court upheld this approach, approving both the shift of pre-trial detention towards goals of public security and the system of presumptions, which, however, have been recently scrutinised as possible grounds for the growing rates of pre-trial incarceration. As a matter of fact, since the 1984 Act was enacted, rates of pre-trial detention grew in a constant manner (from 2000 to 2016 it grew up from 53 to $59 \%$ ) $^{54}$, generating a number of concerns in both social and economic terms. It cannot be overlooked that, in 2016, the average pre-trial detention period was 255 days (over 400 days in several districts), generating huge public expenditure. At the same time, the purpose of separating the right to release and personal financial situation could not be accomplished and the movement for bail reform is one rare area of bi-partisan agreement, pushing for abandoning monetary bail, in favour of effective management of risk. ${ }^{55}$ In fact, given these premises, there are branches of legal research suggesting that presumptions should be replaced by solutions offering a more accurate and flexible representation of reality: models of pre-trial risk assessment.

\section{What ELSE, INSTEAD OF PRESUMPtions?}

As clarified above, models are based on quantitative and statistics approach, which relies on facts recurring in the past. Briefly, what repeatedly happened in the past is suitable to forecast what will happen in the future: given the definition reported in $\S 1$, a model is one possible representation of reality, allowing to draw a prediction of incoming events. Each model is based on a theory aspiring to represent reality, in hard science as much as in social science.

state, or local level. However, the Previous Violator Presumption has three pre-conditions: Has the defendant a prior conviction that would trigger this presumption? Was that prior offense committed while the defendant was released on bail for an unrelated matter? Has less than five years passed from the date of conviction or from the defendant's release for that conviction? If the three conditions are met, the Previous Violator Presumption applies. AUSTIN, A. The Presumption, p. 53. 
Moving from this assumption, it is possible to say that since the beginning of the $20^{\text {th }}$ century a growing reliance on psychology and sociology boosted expectations in the prediction of individuals' future behaviour and in the possibility to prevent reoffending by those who had already been sentenced. However, the discussion led to very different results in Europe and the US, due to a different attitude towards social science and specific approaches to the rule of $\mathrm{law}^{56}$.

\subsection{Continental Europe and the German Moderne Schule}

As to Europe, the beginning of the last century experienced the clash between the 'classic' penological ideology, based on retribution, and the so-called positivistic ideology, promoted in particular by the German Moderne Schule. This was inspired by the ideal that criminal law is a form of social control, and thus promoted a preventative purpose for the penalty ${ }^{57}$. Such a theoretical trend is often defined, in the continental literature, as 'utilitarian-functionalist', ${ }^{58}$ after Jeremy Bentham's traditional paradigm. ${ }^{59}$ In fact, this approach tends to curb criminal law into an instrument to achieve a specific result, i.e., social control. In this view, culpability, the traditional foundation for penalty, ${ }^{60}$ may turn out to be incompatible with the purpose of maintaining (or restore)

56 PIFFERI M., Individualisation of Punishment and the Rule of Law: Reshaping Legality in the United States and in Europe between the $19^{\text {th }}$ and $20^{\text {th }}$ Century, American Journal of Legal History 2012, p. 326.

57 PELISSERO, M., Pericolosità sociale e doppio binario. Vecchi e nuovi modelli di incapacitazione, Giappichelli, Torino, 2008, p. XIV.

58 BARTOLI, R., Colpevolezza tra personalismo e prevenzione, Giappichelli Torino, 2005, p. 43.

59 Although Bentham, in his theories about punishment, was very clear in rejecting unjust sanctions. As punishment is always evil, it can be accepted only if the offender's suffering can spare major suffering to others. TONRY, M., Sentencing and Prediction. Old Wine in Old Bottles, in DE KEIJSER, J.W, ROBERTS, J.V., RYBERG J., Predictive Sentencing. Normative and empirical perspective, Hart Publishing, Oxford, 2019, p. 284.

${ }^{60}$ The principle of culpability is the premise of the state's power to punish: KAUFMANN A., Das Schuldprinzip, Winter, Heidelberg, 1961, p. 15 ff. 
social order, ${ }^{61}$ troubled by crime. Several continental jurisdictions, were influenced by the so called 'positive school', and adopted a twotoer system, based on both penalties and correctional measures, the first being proportional to the act, the second to the social risk posed by the convicted ${ }^{62}$. Actually, such distinction provided for the clear distinction between desert and dangerousness, giving the latter its own specific relevance in the criminological theory. As a result of this distinction, the majority of the European jurisdictions confirmed the tradition of establishing minimum and maximum sentences with regard to every offence, ${ }^{63}$ while common law systems stuck to the tradition of undetermined sentences, making sentencing a process detached from criminal law rules and principles. ${ }^{64}$

\subsection{THE US AND UNDETERMINED SENTENCING}

In fact, in the US, the debate about individualisation of punishment pushed the system towards undetermined sentencing, moving the discretion about the period of detention from courts to boards of experts ${ }^{65}$. This trend had been theorised in the ' 70 s of the $19^{\text {th }}$ century, but was not generally accepted: in fact, it appeared inconstant with the traditional principles of nulla poena and punitur quia peccatum est ${ }^{66}$. First, the traditional balance between legislative, judicial and administrative powers was in jeopardy: not only would the undetermined sentence deprive the Parliament of the power to establish minimum and maximum penalties (as provided by the Constitution), but it would also replace the judicial discretion in

61 JACOBS, G., Das Schuldprinzip, in Rheinische-Westfälische Akademie der Wissenschaften, Vorträge G 319, 1993, p. 8.

62 For an interesting overview on how the U.S. Sentencing Commission tried to reconcile these two paradigms: DUBBER M.D., HÖRNLE T., Criminal Law. A Comparative Approach, OUP, Oxford, 2016, p. 9.

63 PIFFERI M., Individualisation, p. 355.

64 See NORRIE A., Crime, Reason, p. 334: «Once we get beyond the conviction of the accused, the rules and principles of the criminal law tend to evaporate and the system becomes much more discretionary and less regulated by law». PIFFERI M., Individualisation, p. 338. can History, Basic Books, New York, 1994, pp. 159 ff., 304 ff. 
sentencing, with an administrative board's arbitrariness, departing from the general principles of criminal law. Second, the fundamental beacon of the whole of Western ideology, free will, seemed to be under attack. Guilt and punishment were shifted from culpability (i.e. blameworthiness of one's own free behaviour) to the field of the offender's character and criminological type.

However, there was bitter criticism about the criminal justice system of the time. The US was experiencing massive distress because of patent differences in sentencing among federal States. Legal historians report a huge concern for bias and the arbitrariness of courts, scarcely directed by local criminal rules in the overwhelming duty of determining criminal sanctions. Against this backdrop, the proposal of allocating sentencing to experts' boards, operating on the basis of one common index, i.e. science, turned out to be successful. The opinion that delivering the sentence and its periodical review were to be considered, more correctly, administrative duties, rather than judicial, gained momentum, suggesting that they should be performed by an administrative body ${ }^{67}$ with no need of specific Constitutional amendments: the law still provided for a minimum and maximum sentence and courts still had the power to assess guilt, for the sake of the rule of law... ${ }^{68}$ Apparently, this was enough to overcome the fear of 'administrativisation' of criminal justice, which occurred with a general spreading of progressive treatment and experts' boards, by the 20's of the 20th century. This was to become a benchmark, distinguishing the US and the European continental tradition.

In the U.S., the $20^{\text {th }}$ century became the flourishing era of predictive sentencing, boosting psycho-criminological research upon the risk of violent behaviour and recidivism. These were the origins of risk assessment, and they explain why the latter has always been associated with incapacitation, in a paradigm of removal of dangerous individuals from society, until a full recovery from dangerousness.

\footnotetext{
67 Woods v. State,130Tenn.100,114(1914).

68 WARNER C.D., Some aspects of the indeterminate sentence, Yale Law Journal, 1899, p. 222.
} 


\subsection{THE DAWN OF RISK ASSESSMENT TOOLS}

Since those moments on, risk assessment is the main instrument for evaluating potential re-offending. The term is not specific at all, as it is used in many different technical and scientific areas. However, it is in the criminal justice setting that it received the most contradictory reactions ${ }^{69}$. Nevertheless, it has become crucial in several areas of decision-making, both at the pre-trial stage, sentencing and parole, and also in the followup of psychiatric situations. ${ }^{70}$

Moving from the speculation that "nothing predicts behaviour like (or better than) previous behaviour"71, "such tools include a set of risk factors, which may or may not be weighted, to provide a classification of risk (high, medium, low) a probabilistic score (i.e., a percentage probability of re-offending within a certain timeframe) or both". ${ }^{72}$ As seen above, both in general and in specific forensic terms, the matter is the validation of methods and instruments, that must obtain acceptance by the scientific community.

As risk always entails uncertainty ${ }^{73}$, identifying risk factors is the first challenge for scholars and practitioners in the field. Criminal behaviours have multiple causation factors and an offender's risk assessment always take into account the interaction of several factors. A second fundamental step in understanding risk assessment is the relationship between the group and the individual. Social sciences collect statistical data to elaborate general conclusions, applicable to groups of cases. The 'G2I' (Group to Individual) paradigm is at the core of the debate about forensic predictive tools. Prediction of future behaviour can

69 ZARA, G, FARRINGTON, D.P., Criminal Recidivism: explanation, prediction and prevention. Rutledge, Oxon, 2016, p. 148.

71 KVARACEUS, W.C., Anxious Youth: Dynamics of Delinquency, Columbus, Charles E. Merrill Publ., 1966, p. 53,

72 FAZE,L S., The Scientific Validity of Current Approaches to Violence and Criminal Risk Assessment, in DE KEIJSER J.W., ROBERTS, J.V., RYBERG,J, Predictive Sentencing, Normative and empirical perspective, Hart Publishing, Oxford, 2019, p. 197.

73 GIGERENZER, G., Rationality for Morals, OUP, Oxford, 2008, passim. 
only be based on the observation of a group, and is a function of group outcomes: let us see how deeply the G2I effect may affect the reliability of a risk assessment model.

The first step of any risk assessment model is listing causational factors triggering criminal behaviour. Risk factors are usually divided into two groups: static and dynamic. The first do not change, or change in only one possible direction (e.g. age). The latter (dynamic) may change according to the individual's situation and they include criminogenic needs, i.e. aspects of a person, or her personal conditions that, when changing, may set off a variation in her criminal behaviour. There is no evidence that either static or dynamic factors are more reliable indicators of risk: both insufficient per se, they must be taken into account jointly, for a successful assessment. Unfortunately, it is unrealistic that a tool may consider every possible risk factor ${ }^{74}$ : nevertheless, this fact does not prevent models of risk assessment to be reliable.

The accuracy of a scientific prediction is based on the largest sample possible, i.e., the greatest number of cases examined. In particular, a forensic prediction is reliable if it correctly demonstrates the individual's propensity to re-offend. Here the G2I factor steps in: the scale of these two evaluations (suitability and adequacy of the sample; reliability of the prediction with regard to a specific individual) is different and, for this reason, risk assessment is often criticised for its inaccuracy in translating group phenomena into individual instances ${ }^{75}$... As said above, models are not the mirror of reality, they only aspire to describe reality.

One factor may have a relevant impact on the G2I factor. The instruments to enact practical, individual risk assessment may be different, due to the approach they use in translating psycho-criminological theories into a personal evaluation. One main, traditional, distinction is between actuarial instruments and clinical, professional, judgment instruments. For a basic distinction, it is possible to say that actuarial instruments address historical and static risk factors, while professional judgment instruments take into account dynamic risk factors. While the professional approach encompasses the professional's experience and intuition - but,

74 ZARA, G. FARRINGTON D.P., Criminal Recidivism, p. 155.

75 REDMAYNE. M., Character in Criminal Trial, OUP, Oxford, 2015, p. 258. 
also her unconscious bias - the static risk evaluations tend to portray an individual as unchangeable, without taking into account the effect of a possible evolution in her condition, influencing the risk of (re)offending.

\subsection{PRE-TRIAL RISK ASSESSMENT TOOLS: THE PTRA}

As mentioned above, in the US, the high dissatisfaction with pretrial incarceration rates set possible alternatives to presumptions under the spotlight. Based on the large experience gathered in the realm of sentencing and parole risk assessment tools, several solutions have been tailored for both the federal and the local level.

At the federal level, the Probation and Pretrial Service Office, Administrative Office of the U.S. Courts, assigned Christopher Lowenkamp with the design of a specific tool, meant to assist pre-trial federal officers in preparing recommendation before detention hearings ${ }^{76}$ : in 2010 he released the Pretrial Risk Assessment Tool (PTRA), which is extensively used, and regularly revised, in order to re-assess its validation ${ }^{77}$.

The instrument is actuarial, based on large archive data, originally encompassing 200.000 federal cases of release, from 2001 to 2007. The instrument rates the defendant's risk of failure to appear (FTA), rearrest for new criminal activity, pretrial revocation of release.

Inspired by regression modelling techniques, the PTRA algorithm is based on 11 parameters that, according to Lowenkamp's theory, accurately score the individual's specific pre-trial risk. Such parameters are: defendant's criminal history (number of felony convictions; prior failure to appear; pending felonies and misdemeanors); instant conviction offence (type and class); age, educational achievements; employment status; residential location and ownership; problems of drug or other substance abuse; citizenship status. Given these data, the tool scores suspects in a range of five risk categories, from 0 to 15, predicting the likelihood that the they commit pre-trial violations.

76 AUSTIN, A., The Presumption, p. 54.

77 COHEN, T.H., LOWENKAMP, C.T., HICKS, W.E., Revalidation the Federal Pretrial Risk Assessment Instrument (PTRA): A Research Summary, Federal Probation, 2018, vol. 82, n. 2, p. 23 ff. 
This brand-new instrument was set in the hands of federal pretrial officers (civil servants who, according to $§ 1354$ of the bail Reform Act, are in charge of collecting, verifying and reporting judicial officials on information about the risks posed by a defendant in terms of flight and social danger). In 2014, only half of the pre-trial reports handled by pre-trial officers to judicial officials was based on PTRA, while in more recent years, the use became larger ${ }^{78}$.

\subsection{AND THE PSA}

As to local dimension, one tool is widely used in the US, in pretrial detention and release decisions ${ }^{79}: 28$ jurisdictions (and among them three States) ${ }^{80}$ use the Public Safety Assessment (PSA) ${ }^{81}$ to assist the judge in the decision about the risks of leaving the accused at large, before trial. The software was developed in 2013 and, according to the institution that promoted it (the Laura and John Arnold Foundation) ${ }^{82}$, it is useful in reducing the number of individuals detained before trial. ${ }^{83}$ Based on

78 COHEN, T.H., LOWENKAMP, C.T., HICKS, W.E., Revalidating, p. 29.

79 KEHL, D., GUO, P., KESSLER, S., Algorithms in the Criminal Justice System: Assessing the Use of risk Assessments in Sentencing, Responsive Communities Initiative, Berkman Klein Center for Internet \& Society, Harvard Law School, 2017, available at http://nrs.harvard.edu/urn-3:HUL.InstRepos:33746041, p. 10.

80 PSA was developed and piloted in Kentucky. Before the instrument was released, a local law (House Bill, 463, 2011) made the use of risk assessment mandatory in bail decisions. Since its launch in 2013, PSA spread to other 27 jurisdictions (among which, 2 other States) and has been pointed out as the scheme for a general bail review bill (Pretrial Integrity and Safety Act), presented in 2017 at the US Senate by Senators Kamala D. Harris (dem.) and Rand Paul (rep.) (read their opinion at https://www.nytimes.com/2017/07/20/ opinion/kamala-harris-and-rand-paul-lets-reform-bail.html).

81 https://www.psapretrial.org/about/background

82 The foundation was established in 2010 by Laura (an attorney and former oil company executive), and John (an investor) Arnold.

83 https://www.psapretrial.org/about/background. However, STEVENSON, M.T., Assessing Risk Assessment, p. 305, highlights that arguments and 'facts' usually reported in the discussion about risk assessment stem form non-academic reports by the agencies that designed the instruments. 
9 factors,${ }^{84}$ the instrument is actuarial, relying on the individual's age, current charge and criminal history: race, ethnicity and geography are not taken into consideration as, according to the designers, they would not improve accuracy in prediction. The instrument is said to having been created on the basis of the largest dataset ever collected, i.e. 750.000 cases, from about 300 jurisdictions: according to the designers, this makes it a nationally-wide validated tool.

The tool does not need an interview with the accused: the information can be taken out of her criminal record and other general record accessible to the public authority. Based on algorithms tailored to purpose, the tool produces a scale of the individual's risk under three different parameters (FTA, Failure To Appear; NCA, New Criminal Activity; NVCA, New Violent Criminal Activity), that can be used by a judge or a court, along with the so-called Decision-Framework, ${ }^{85}$ to decide whether the arrested will be released or detained. The peculiarity of this instrument is the ability to deliver a 'Failure To Appear' index. The risk factors considered by PSA under this parameter are: Pending charge at the time of offense (Y/N); Prior conviction (Y/N); Prior failure to appear in the past 2 years (No/Once/2 or more times); Prior failure to appear, older than 2 years $(\mathrm{Y} / \mathrm{N})$.

The more traditional monetary bail proved discriminatory towards the poorest social groups ${ }^{86}$ (and, thus, potentially in breach of the Eighth Amendment to the Federal Constitution), ${ }^{87}$ the quicker this

84 Age at current arrest; Current violent offense (current violent offense and 20 yrs. old or younger); Pending charge at the time of the offense; Prior misdemeanor conviction; Prior felony conviction (prior conviction [misdemeanor or felony]); Prior violent conviction; Prior failure to appear in the past two years; Prior failure to appear older than two years; Prior sentence to incarceration

85 https://www.psapretrial.org/implementation/guides/managing-risk/ guide-to-the-pretrial-decision-framework. According to the text, «the PSA is used to measure a person's pretrial risk, whereas the DF is used to help manage that risk»

86 See Criminal Justice Policy Program, Harvard Law School, Moving Beyond Money: A Primer on Bail Reform, 2016, Harvard Law School, 6 ff.

87 The Eight Amendment prohibits “excessive bail”, but, unfortunately, it does not define the meaning of 'excessive'. 
pretrial risk assessment tool spread around the US ${ }^{88}$, pushed by a strong movement for reforming bail throughout the US, prioritising effective risk management over monetary bonds, and gaining momentum in pretrial services programs, focusing both on release and diversion. ${ }^{89}$

There are few studies focusing on the real impact of the use of pretrial risk assessment. Some researchers have highlighted that the effects of it are scarce and not permanent..$^{90}$ Given that pretrial risk assessment is a relatively new trend, based on the recent mistrust and critique of traditional monetary bail bonds, its advocate argue that the burdensome, awful, monetary bond may prove useless in bail decisions, if «in principle an algorithm could also make these predictions. Just as pixel patterns can be used to predict presence of a face, information about the defendant and their case could be used to predict flight or public safety risk ${ }^{91}$.

What is radically new, in the two pre-trial risk assessment models presented here, is the FTA index. I reported above the factors that PTRA and PSA consider to be relevant for the evaluation of the individual's propensity to abscond. However, apparently there is no comprehensive and fully independent literature about the meaningfulness of those factors in terms of effective risk of flight. While criminogenic factors at the basis of sentencing risk assessment have been widely discussed by scholars, over the last century, at least, it seems to me that there is no sufficiently convincing academic literature demonstrating the relevance of the FTA factors. On the one hand, it is important to understand if and how judges apply the PSA report, taking into account first instance and

88 STEVENSON M.T., Assessing Risk Assessment, p. 307. reform passed in Kentucky was an immediate boost in non-monetary release and, in general, an increase in release of moderate-risk accused. Nevertheless, in the following two years, the effect was reversed and the remand on custody rates became higher than they were before the reform. The introduction of PSA had no significant results in terms of release rates ad it seems that only $29 \%$ of arrested are released on non-monetary bond at the first bail setting.

91 KLEINBERG J. ET ALII, Human Decisions and Machine Predictions, The Quarterly Journal of Economics, 2018, p. 240. 
appeal pre-trial decisions ${ }^{92}$. On the other hand, there is a lack of literature demonstrating that the incorporation of those factors into an actuarial instrument can outperform the judge's individual evaluation. Secondly, it turns out to be complicated for scholars, to compare algorithmic pretrial risk assessment tools with judicial decisions, because of the ambiguity of judges' predictions. In fact, a defendant can be remanded in custody both because the judge estimated a high risk of absconding (or offending), or simply because the judge overestimated her ability to pay, establishing a bond that she cannot afford. Moreover, the judge's individual evaluation can be influenced by factors other than risk, such as proportion with the current charge, notwithstanding a high score in risk of absconding or offending. ${ }^{93}$ Thus, only a rough proxy can be used as a measure of human performance in estimating pretrial risk... ${ }^{94}$ Taking into account all these arguments, scholars have argued that it is unclear whether digital pretrial risk assessment tools really outperform humans at predicting pretrial risks ${ }^{95}$. However, I suggest to move the spotlight from the specific aspect of measuring if and how much pre-trial risk assessment models can outperform humans in detecting real risk, to a different issue: how can pre-trial measure decisions become more compliant with the presumption of innocence?

92 MINDE, B. D., FARRELL E.A., The Role of Public Safety Assessment in Pretrial Detention, New Jersey Lawyer, 2019, n. 318, p. 29 ff. report of several New Jersey cases of court's criticism about PSA reports.

93 It is worth remembering that some jurisdiction (e.g. the Italian one), provide for a specific principle of proportionality, in pretrial coercive measures, between the offence the arrested is charged with and the measure to be applied. The first index to be considered by the judge is proportionality to the current charge and the second is adequacy to the effective risk of the case (of absconding, or tampering with evidence, or offending), being detention being the last resort.

STEVENSON, M.T., Assessing Risk Assessment, p. 324.

STEVENSON, M.T., Assessing Risk Assessment, p. 325. Moreover, due to the fact that instruments like PSA are based solely on information taken out of files and records, with no need for an interview with the defendant, some have criticised their structure. It sounds contradictory to claim for reform of the bail system by suggesting instruments that are completely based on data pulled from the system under reform itself: LOGAN KOEPKE J., ROBINSON D.G., Danger Ahead, p. 1751. 


\section{Conclusions}

The idea at the basis of this paper is that the purpose of taking advantage of the recent digital turn to design pre-trial risk assessment tools is just a modern attempt to tackle the same, old problems of justifying pre-trial detention decisions, against the backdrop of the presumption of innocence.

In the wake of the so-called fourth revolution, the scholars' duty is to consider, neutrally, how the two different methods perform. On the one hand, traditional presumptions of pre-trial risks have been recently coupled, in the U.S. criminal justice system, with actuarial risk assessment tools, meant to deliver accurate and individual predictions about the suspect's future behaviour. As reported by a recent study, PTRA proved much more nuanced and effective in identifying high risk suspects than traditional presumptions, the latter being «a poorly defined attempt to identify high-risk defendants based primarily on their charge, relying on the belief that a defendant's charge was a good proxi for that defendant's risk ${ }^{96}$. Nuanced and effective, rather than outperforming, appears to be much more appropriate terms to face the challenge of reconciling pretrial detention with the presumption of innocence...

On the other hand, Italy is an example of persistence in pre-trial detention presumptions, even if the Constitutional Court triggered a trend of strong reduction of the irrebuttable presumption. No others solutions have been envisaged so far and I do not suggest that actuarial instruments may be the solution. However, what these two different experiences demonstrate is that the legal standards set by rulers and courts for pretrial risks forecast cannot but be general. Nevertheless, both the basic principles of fair trial and reality proved that an accurate prediction is an individualised one, which can hardly be performed on the basis of the sole legal standards. This is demonstrated by the recent Italian reform, of 2015, meant to reinforce the judicial duty to give extremely precise reasoning of pre-trial measures: as a matter of fact, listing long catalogues of checks and balances that judges must report in their decisions did not improve the quality of the judicial control over pre-trial coercive measures ${ }^{97}$ and

\footnotetext{
96 AUSTIN, A., The Presumption, p. 60.

97 ZACCHÉ, F., La libertà, p. 2004.
} 
did not reduce neither the rates of pre-trial detention, nor the number of pre-trial measures appeals. Forecasting one of the traditional pre-trial risks is a matter of being provided with complete, updated, accurate information about the suspects and their personal environment. Such prediction cannot be based on normative assumptions rather than on factual data and for these reasons, presumptions cannot fulfil the task.

Can actuarial pre-trial risk assessment tools do it? In previous occasions I stated that, as to the Italian legal system, such instruments should not be used, neither in trial nor at the pre-trial stage, due to the general provision of art. 220.2 ItCCP, prohibiting the use of psychocriminological expertise before sentencing. Although still convinced of that belief, I must admit that reflecting upon the topic of this paper, I started approaching the idea that more accurate decisions in pre-trial coercive measures do not depend on better legal formulas, rather than more informed judicial decisions. Given the crucial role of judges' discretion in every single case (and the paramount importance of a detailed reasoning), non-normative standards may guide them in a more individualised decision, possibly reducing pre-trial incarceration rates, provided that those standards are accurate, validated and are not used to rule out the duty of an exhaustive reasoning ${ }^{98}$.

Actually, besides risk assessment tools, the recent digital turn can offer wide range information about suspects, that may turn out to be particularly useful in pre-trial detention decisions, when the file is slim and the judge has no personal acknowledgment of the suspect's personal conditions, especially in those legal orders, such as Italy, in which there is no contact between judges and suspects, before the decision upon pretrial measures is taken. Having more information about the individual under investigation, the judge could, e.g., better understand that, due to her special family conditions, it is extremely unlikely that the defendant may flee. And digital analytics may certainly help in tracing a complete profile of the suspect.

98 Daniele, M., Il diritto alla libertà personale e le manipolazioni dell'habeas corpus, in Negri D., Zilletti L. (eds.), Nei limiti della Costituzione. Il codice repubblicano e il processo penale contemporaneo, Cedam, Padova, 2019, p. 221: the Author forecasts a scenario in which pre-trial risk assessment tools may rule out or reduce the impact of reasoning in pre-trial decisions. 
However, we should wonder how this impacts on the presumption of innocence: should we assume that a more informed decision, based on a digital analysis of data, necessarily affects such presumption? Actually, the correct point of view seems to be the one mentioned at the beginning. It has been largely acknowledged that the limit of compliance of pre-trial coercive measures with the presumption of innocence is the specific purpose of such measures. As far as they are meant to avoid disruptions in the procedure, such as tampering with evidence or flight, they have been largely accepted ${ }^{99}$ as compliant with the presumption of innocence. In the same way, the use of digital solutions for the decision upon such measures does not add, in my opinion, specific risks for the presumption of innocence, as far as such purpose is respected. In fact, as it has also been empirically demonstrated ${ }^{100}$, the major area of infringement of the presumption of innocence derives from the use of pre-trial detention as a means of prevention of crime ${ }^{101}$, for purposes of social security.

Given that pre-trial risk assessment tools appear to be deprived of evidence-based reliability with regard to the prediction of the risk of tampering and fleeing, digital instruments providing pre-trial judges with more information to consider, do not seem to impinge, negatively, on the suspect's presumption of innocence. However, a basic condition for this assumption is the reliability and the neutrality of such information, which

99 See however the provoking opinion by Duff, A., Pre-Trial Detention and the Presumption of Innocence, in Ashworth A., Zedner L., Tomlin P. (Eds.), Prevention and the Limits of the Criminal Law, Oxford University Press, Oxford, 2013, p. 115 ff. For a general overview upon the relationship between presumption of innocence and the persistent trend to extend the use of pre-trial detention: STEVENS, 1., Pre-Trial Detention: The Presumption of Innocence and Article 5 of the European Convention on Human Rights Cannot and Does Not Limit Its Increasing Use, in European Journal of Crime, Criminal Law and Criminal Justice, Vol. 17, Issue 2 (2009), pp. 165 ff.; MEYERS, N.M., Eroding the Presumption of Innocence: Pre-Trial Detention and the Use of Conditional Release on Bail, in British Journal of Criminology, 2017, pp. $664 \mathrm{ff}$.

100 STEVENS, L., The meaning of the presumption of innocence for pre-trial detention: An empirical approach, 42(3) Netherland Journal of Legal Philosophy, 2013, 239-248, p. 242.

${ }^{101}$ See recently, MAZZA, O., La presunzione di innocenza messa alla prova, in La giustizia penale, 2019, 181 ss. 
should be assessed; moreover, software processing such information must be tailored for the specific purpose of being used in criminal proceedings, with specific attention to fundamental rights.

Providing judges with accurate information may induce a trend reducing the need to use presumptions and pre-trial risk assessment tools, leading to a more accurate (and less generalised) application of coercive measures. In this sense, such solution may have, on the contrary, a positive impact on the presumption of innocence. Reaffirming that remand in custody is applied only when specific circumstances highlight a specific risk for the proceeding may foster the feeling, in the public opinion, that pre-trial measures are not an anticipation of penalties, rather restrictions carefully used to succeed in leading an accurate criminal proceeding.

\section{References}

ALSCHULER, Albert, W., Preventive Pre-Trial Detention and the Failure of Interest-balancing Approached to Due Process, Michigan Law Rev., 1986, vol. 85, Issue 3, p. 520 ff.,

ANDRIOLI, Vittorio, Presunzioni (dir. proc. civ.), Novissimo Digesto Italiano, vol. XIII, Utet, Torino, 1966, p. 765 ff.

AUSTIN, Amaryllis., The Presumption for Detention Statute's Relationship to Release Rates, in Federal Probation, 2017, vol. 81, no. 1, p. 52 ff.

BARTOLI Roberto, Colpevolezza tra personalismo e prevenzione, Giappichelli Torino, 2005

CAVADINO Paul, GIBSON Bryan, Bail, The Law, Best Practice and the Debate, Waterside Press, Hook, 1993

CENTORAME, Federica, Presunzioni di pericolosità e coercizione cautelare, Giappichelli, Torino, 2016.

COHEN, Thomas H., LOWENKAMP, Christopher T., HICKS, William E., Revalidation the Federal Pretrial Risk Assessment Instrument (PTRA): A Research Summary, Federal Probation, 2018, vol. 82, n. 2, p. 23 ff.

DANIELE, Marcello, Il diritto alla libertà personale e le manipolazioni dell'habeas corpus, in Negri D., Zilletti L. (eds.), Nei limiti della Costituzione. Il codice repubblicano e il processo penale contemporaneo, Cedam, Padova, 2019 
DANIELE, Marcello, Habeas Corpus. Manipolazioni di una garanzia, Giappichelli, Torino, 2017, $108 \mathrm{ff}$.

DELVECCHIO, Francesca., Presunzioni legali e rieducazione del condannato, Giappichelli, Torino 2020

DUBBER, Markus D., HÖRNLE Tatiana, Criminal Law. A Comparative Approach, OUP, Oxford, 2016

DUFF, Anthony, Pre-Trial Detention and the Presumption of Innocence, in Ashworth A., Zedner L., Tomlin P. (Eds.), Prevention and the Limits of the Criminal Law, Oxford University Press, Oxford, 2013, pp. 115-132.

FANUELE Chiara, La libertà su cauzione: un'alternativa alla custodia cautelare, Cedam, Padova, 2016

FAZEL, Seena, The Scientific Validity of Current Approaches to Violence and Criminal Risk Assessment, J. W. De Keijser, J.V. Roberts, J. Ryberg, Predictive Sentencing, Normative and empirical perspective, Hart Publishing, Oxford, 2019

FRIEDMAN, Lawrence M., Crime and Punishment in American History, Basic Books, New York, 1994

GIGERENZER, Gerd, Rationality for Morals, OUP, Oxford, 2008

GIULIANI, Livia, La libertà personale dell'imputato dopo la 1. 16 aprile 2015, n. 47, in Rivista di Diritto Processuale, 2017, p. 165 ff.

GREVI, Vittorio, Libertà provvisoria ed esigenze di tutela ella collettività: una questione di legittimità costituzionale, Giur.it., II, 1976, 633 ff.

ISRAEL, Giorgio, IANNELLI, Mimmo, Modellistica matematica, Enciclopedia Italiana Treccani, VI Appendice, Treccani, Roma, 2000

JACOBS, Günther, Das Schuldprinzip, in Rheinische-Westfälische Akademie der Wissenschaften, Vorträge G 319, 1993, 7 ff.

JUNG Sina, PETRICK, Carolin, SCHILLER Eva M., MUNSTER, Lukas, Developments in German Criminal Law: The Urgent Issues regarding Prolonged Pre-Trial Detention in Germany, German Criminal Law, 2021, p. 307 ff.

KAUFMANN, Arthur, Das Schuldprinzip, Winter, Heidelberg, 1961.

KEHL, Danielle, GUO, Priscilla, KESSLER, Samuel, Algorithms in the Criminal Justice System: Assessing the Use of risk Assessments in Sentencing, Responsive Communities Initiative, Berkman Klein Center for Internet \& Society, Harvard Law School, 2017, available at http://nrs.harvard.edu/urn-3:HUL.InstRepos:33746041 
KIESELBACH, Daniel, Pre-Trial Criminal Procedure: Preventive Detention and the Presumption of Innocence, in Criminal Law Quarterly, 1989, vol. 31, n. 2., p. $171 \mathrm{ff}$. KLEINBERG, Jon, et alii Human Decisions and Machine Predictions, QJ Econ, 2018, $237 \mathrm{ff}$.

KVARACEUS, William C., Anxious Youth: Dynamics of Delinquency, Columbus, Charles E. Merrill Publ., 1966

LACEY, Nicola. State Punishment, Rutlege, London-New York, 1988

LOGAN KOEPKE, John, Robinson David G., Danger Ahead: Risk Assessment and the Future of Bail Reform, Washington Law Review, 2018, $1731 \mathrm{ff}$.

MANES, Vittorio, Lo 'sciame di precedenti' della Corte costituzionale sulle presunzioni in materia cautelare, Diritto Penale e Processo, 2014, p. 457 ff.

MAZZA, Oliviero, La presunzione di innocenza messa alla prova, in La giustizia penale, 2019, 181-192.

MEYER, Hermine H., Constitutionality of Pretrial Detention, The Georgetown Law Journal, 1972, vol. 60, n. 6, p. 1469 ff.

MEYERS, Nicoles M., Eroding the Presumption of Innocence: Pre-Trial Detention and the Use of Conditional Release on Bail, in British Journal of Criminology, 2017, pp. 664-683

MINDE, Brandon, D., FARRELL Elizabeth A., The Role of Public Safety Assessment in Pretrial Detention, New Jersey Lawyer, 2019, n. 318, p. 29 ff.

MORENO CATENA, Victor, Spain, in S. Ruggeri (ed), Liberty and Security in Europe, Universitätsverlag Osnabrück, Göttingen, 2013, 141 ff.

NEGRI Daniele, L'imputato presente al processo, Giappichelli, Torino, 2014,

NORRIE, Alan, Crime, Reason and History. A Critical Introduction to Criminal Law, CUP, Cambridge, 2014

ORLANDI, Renzo (2013), Introduction, in Ruggeri Stefano (ed), Liberty and Security in Europe, Universitätsverlag Osnabrück, Göttingen, 9 ff..

PAGALLO, Ugo, Algo-Rithms and the Beat of the Legal Drum, in Philosophy and Technology, 2018, 1 ff.

PELISSERO, Marco, Pericolosità sociale e doppio binario. Vecchi e nuovi modelli di incapacitazione, Giappichelli, Torino, 2008.

PIFFERI, Marco, Individualisation of Punishment and the Rule of Law: Reshaping Legality in the United States and in Europe between the $19^{\text {th }}$ and $20^{\text {th }}$ Century, American Journal of Legal History, 2012, 325 ff. 
QUATTROCOLO S., Artificial Intelligence, Computational Models and Criminal Proceedings. A Framework for a European Legal Discussion, Springer, Cham, 2020 REDMAYNE, Michael, Character in Criminal Trial, OUP, Oxford. 2015.

RYBERG, Jesper, Risk and Retribution. On the Possibility of Reconciling Considerations of dangerousness and Desert, in J. W. De Keijser, J.V. Roberts, J. Ryberg, Predictive Sentencing, Normative and empirical perspective, Hart Publishing, Oxford. 2019.

RUGGERI, Stefano, Comparative analysis of pre-trial precautionary measures in criminal proceedings, in S. Ruggeri (ed), Liberty and Security in Europe, Universitätsverlag Osnabrück, Göttingen, 2013, 185 ff.

SCHNACKE, Timoty R., JONES, Michael R., BROOKER, Claire, M.B, The History of Bail and Pretrial Release, Pretrial Justice Institute, 2010

STEVENS, Lonneke, The meaning of the presumption of innocence for pre-trial detention: An empirical approach, Netherland Journal of Legal Philosophy, 42(3), 2013, 239-248

STEVENS, Lonneke., Pre-Trial Detention: The Presumption of Innocence and Article 5 of the European Convention on Human Rights Cannot and Does Not Limit Its Increasing Use, in European Journal of Crime, Criminal Law and Criminal Justice, Vol. 17, Issue 2, 2009, pp. 165-180;

STEVENSON, Megan.T., Assessing Risk Assessment in Action, Minnesota Law Review, 2018, 303 ff.

TONDI, Veronica, Il bail. La libertà su cauzione negli ordinamenti anglosassoni, Cedam, Padova, 2016.

TONRY, Michael, Sentencing and Prediction. Old Wine in Old Bottles, in J. W. De Keijser, J.V. Roberts, J. Ryberg, Predictive Sentencing. Normative and empirical perspective, Hart Publishing, Oxford, 2019, 269 ff.

TRIBE, Laurence H., Trial by mathematics: Precision and Ritual in the Legal process, Harvard Law Rev., 1971, vol. 84, p. 1368 ff.

TRIBE, Laurence H., An Ounce Of Detention: Preventive Justice in the World of John Mithcell, Virginia Law Review, 1970, vol. 56, p. 407 ff.

UNDERWOOD, Barbara D., Law and the Crystal Ball: Predicting Behavior with Statistical Interference and Individualized Judgement, Yale Law Journal, 1979, vol. 88, $1409 \mathrm{ff}$.

VAN NOSTRAND, Marie, Legal and Evidence Based Practices: Application of Legal Principles, Laws, and Research to the Field of Pretrial Services, 2007, Crime 
and Justice institute - National Institute of Corrections, US Dept. Of Justice, Bibliogov, Washington, 2012.

VOGLER, Richard, England and Wales, in S. Ruggeri (ed), Liberty and Security in Europe, Universitätsverlag Osnabrück, Göttingen, 2013, 87 ff.

WARNER, Charles D., Some aspects of the indeterminate sentence, Yale L. J., 1899, p. 219 ff.

WILLIAMS, Jack F., Classifying Pre-Trial Detention Decisions under the Bail Reform Act of 1984; A Statistical Approach, American Criminal Law Review, 1993, Vol. 30, p. 285 ff.

ZACCHÉ, Francesco, La libertà personale tra diritti della persona e nuove sfide del processo penale, in Rivista Italiana di Diritto e Procedura Penale, 2020, 2006 ff.; ZARA, Georgia, FARRINGTON, David P., Criminal Recidivism: explanation, prediction and prevention. Rutledge, Oxon, 2016.

\section{Additional information and author's declarations (scientific integrity)}

Acknowledgement: Thanks to Prof. Livia Giuliani for hosting this paper in her edition.

Conflict of interest declaration: the author confirms that there are no conflicts of interest in conducting this research and writing this article.

Declaration of authorship: all and only researchers who comply the authorship requirements of this article are listed as authors; all coauthors are fully responsible for this work in its entirety.

Declaration of originality: the author assures that the text here published has not been previously published in any other resource and that future republication will only take place with the express indication of the reference of this original publication; she also attests that there is no third party plagiarism or self-plagiarism. 


\section{Editorial process dates}

(http://www.ibraspp.com.br/revista/index.php/RBDPP/about/editorialPolicies)

- Submission: 02/08/2021

- Desk review and plagiarism check: 02/08/2021

- Review 1: 10/09/2021

- Review 2: 21/09/2021

- Preliminary editorial decision: $21 / 09 / 2021$

- Correction round return: 04/10/2021

- Final editorial decision: 04/10/2021

\section{Editorial team}

- Editor-in-chief: 1 (VGV)

- Associated-editor: 2 (BC, LG)

- Reviewers: 2

\section{HOW TO CITE (ABNT BRAZIL):}

QUATTROCOLO, Serena. Forecasting the future while investigating the past. The use of computational models in pre-trial detention decisions. Revista Brasileira de Direito Processual Penal, vol. 7, n. 3, p. 1859-1896, set./dez. 2021. https://doi.org/10.22197/rbdpp.v7i3.633

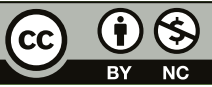

Esta obra está licenciada com uma Licença Creative Commons Atribuição-NãoComercial 4.0 Internacional. 